\title{
Human Platelet Rich Plasma Alleviates Liver Fibrosis in Murine Schistosomiasis Mansoni
}

\author{
BAHAA EL-DEEN W. EL-ASWAD, Ph.D.*; SAMAR A. EL-REFAI, M.D.*; \\ SHEREEN F. MAHMOUD, M.D.** and MOHAMED A. HELWA, M.D.*** \\ The Departments of Medical Parasitology*, Pathology** and Clinical Pathology***, Faculty of Medicine, Menoufia University
}

\begin{abstract}
Background: Schistosoma (S.) mansoni infection leads to hepatic fibrosis that may cause severe complications. Currently, there is no effective medication against schistosomiasis liver fibrosis.

Aim of the Work: The aim of the present study was to evaluate the anti-fibrotic effects of human platelet rich plasma (PRP) against S. mansoni liver fibrosis in experimentally infected mice alone or in combination with praziquantel (PZQ).

Materials and Methods: Seventy male BALB/c mice were divided into five mice groups; group I: Uninfected control (UC, $n=10)$; group II: Infected, untreated (IU, $n=15)$; group III: infected, treated 8 weeks post-infection (p.i.) with PZQ (PZQ, $n=15)$; group IV: Infected, received 8 weeks p.i. PRP $(P R P, n=15)$ and group $V$ : Infected, treated 8 weeks p.i. with $\mathrm{PZQ}$ then received $\mathrm{PRP}(\mathrm{PZQ}+\mathrm{PRP}, \mathrm{n}=15)$. All the mice were euthanized at 12 weeks p.i then parasitological, histopathological, immunohistochemical studies were done in addition to measuring of serum liver enzymes.
\end{abstract}

Results: $\mathrm{PZQ}+\mathrm{PRP}$ significantly reduced $(p<0.001)$ the mean liver granuloma diameter by $71 \%$, followed by PRP $(51.2 \%)$ and then PZQ (33.8\%). Also, PZQ+PRP achieved the highest reduction in the liver fibrosis $(73.3 \%)$, whereas PRP achieved $63.8 \%$ reduction in the fibrosis and this was better than that revealed by PZQ (50.8\%). On immunohistochemical examination of the liver sections, $P Z Q+P R P$ caused the least expression of alpha smooth muscle actin (a-SMA), transforming growth factor- $\beta 1$ (TGF- $\beta 1$ ) and inducible nitric oxide synthase (iNOS), while it induced the strongest caspase3 expression, among the treated mice groups, in comparison to IU mice. PRP alone or in combination with PZQ significantly decreased serum liver enzymes comparing to IU mice.

Conclusion: PZQ+PRP significantly reduced S. mansoni induced liver fibrosis in association with improving the liver enzymes. So, it is recommended to treat $S$. mansoni liver fibrosis by both PZQ and PRP, and this could be applicable in case of human liver fibrosis caused by schistosomiasis mansoni.

Key Words: S. mansoni - Fibrosis - PRP - Immunohistochemistry.

Correspondence to: Dr. Bahaa El-Deen W. El-Aswad, e-mail: bahaaelaswad@gmail.com

\section{Introduction}

SCHISTOSOMIASIS is a common neglected parasitic disease coming next to malaria in its predominance [1]. Around 260 million individuals demanded the anti-Schistosoma treatment in 2014 [2].More than 300,000 deaths per year are reported as a consequence of schistosomiasis-induced liver fibrosis and its sequelae, particularly hematemesis

Some of Schistosoma deposited ova might be trapped in numerous tissues, especially the liver. The ova discharged soluble antigens can instigate $\mathrm{T}$ helper (Th) 2 immune response resulting in inflammatory granulomatous reactions and therefore development of fibrosis [4]. In human, the hepatic fibrotic changes may cause dangerous complications. For example, hepatomegaly, portal hypertension and oesophageal varices with hemorrhage tendency that are frequently the main cause of death [5].

Hepatocytes stellate cells (HSCs) are the fundamental cells associated with pathogenesis of schistosomiasis hepatic fibrosis [6]. Under normal physiological conditions, these cells stay quiescent in space of Disse and function to accommodate vitamin A store. Once liver injury occurs, HSCs transdifferentiate into myo-fibroblasts, where they lose their vitamin A storage capacity with more expression of a-SMA that enhances their contractile activity. Myo-fibroblasts secret large amounts of extracellular matrix (ECM) components mainly collagen enclosing hydroxyproline, in addition to profibrogenic cytokines and chemokines which can attract various immune cells to the granuloma area [6]. TGF- 331 is reported as the most important pro-fibrogenic cytokine which prompts HSCs activation and fibrosis progression [7]. 
During Schistosoma infection, the prompted oxidative stress is assuming an imperative part in developing hepatic fibrosis [8]. Nitric oxide (NO) is a free radical synthesized by three NO synthase enzymes; endothelial, neuronal and inducible (iNOS) and the latter one is expressed by many cell types when subjected to infection or injury. When produced, NO quickly binds superoxide anion $(\mathrm{O} 2-)$ forming reactive peroxynitrite (ONOO-) which mediates oxidization of cellular structures, lipid peroxidation and impairs the functions of many intracellular enzymes [9]. Additionally, NO has been associated with tissue fibrosis as it induces production of many fibrogenic cytokines [10]. Apoptosis is a programmed cell death, characterized by DNA fragmentation and chromatin condensation. It includes two signaling pathways, intrinsic and extrinsic, which are mediated by activation of caspase cascade that ends with caspase3 activation causing cell death [11]. Activation of protease caspase- 3 might be involved in death of the activated HSCs, so it could have a role in hindering the fibrosis prosses [12].

Until now, there is no efficient medication for treatment of liver fibrosis. PZQ is the fundamental anti-schistosomiasis drug for more than forty years now. It is effective against adult worms of all schistosome species. However, its effect is less towards the immature larvae [13]. Furthermore, PZQ shows low capacity to invert tissue damage or liver fibrosis caused by the parasite eggs [14]. It has been proposed that early treatment of liver fibrosis could be more valuable, as it lessens liver cirrhosis which advances to liver cancer [15] .

Platelet rich plasma (PRP) is a highly concentrated platelets preparation coming to around five times more than their normal blood count. The utilization of PRP as a regenerative medication has quickly developed to incorporate wide varieties of clinical conditions including ulcers, bone diseases and tissue damage [16,17]. PRP releases numerous mediators like cytokines, chemokines and growth factors into the affected areas to initiate their recovery through expanding, proliferation and relocation of vital cells [18]. Additionally, platelets collected from human [19] or animals $[20,21]$ have alleviated chemically-induced liver fibrosis in in-vivo experiments. Moreover, Maruyama et al., [22] found that patients having liver fibrosis showed lowering of serum hyaluronic acid; a fibrotic marker, when receving platelet transfusion. In the same context, thrombocytopenia was found to exaggerate liver fibrosis in experimental mice [23]
The current study was done to evaluate the possible anti-fibrotic effects of human PRP on liver fibrosis in experimental $S$. mansoni infection, alone or in combination with $\mathrm{PZQ}$, through assessment of parasitological, histopathological and immunohistochemical parameters in addition to serum liver enzymes. According to our updated knowledge, this is the first study to assess the effect of PRP on S. mansoni induced liver fibrosis.

\section{Material and Methods}

Mice:

Seventy male BALB/c mice (25-27 g in weight) were obtained from the Schistosome Biological Supply Program, Theodor Bilharz Research Institute, (TBRI), Cairo, Egypt from Dec., 2017 - June 2018. The animals were kept in wired cages under ideal states of temperature and humidity with a 12-hours (hrs) light-dark cycle. The mice were given standard eating regimen and tap water $a d$ libitum. Animal handling was carried out following the regulations of TBRI ethical committee.

\section{Parasite and infection:}

Cercariae from the Egyptian strain of S. mansoni were isolated from infected Biomphalaria glabrata snails that were maintained in TBRI and the mice were infected subcutaneously with $80 \pm 10$ cercariae per mouse.

$P Z Q$ :

Praziquantel (EPICO Pharmaceuticals, Cairo, Egypt) was prepared in 2\% Cremophor-EL (SigmaAldrich, St. Louis, USA) and given orally in a dose of $500 \mathrm{mg} / \mathrm{kg}$ for 2 consecutive days beginning at 8th weeks p.i.

\section{PRP preparation:}

Platelet-rich plasma was prepared according to Bausse et al., [24]. Briefly, human venous blood was obtained from healthy volunteers with normal platelet count, without relevant diseases, including schistosomiasis, and with no history of any drug intake known to affect platelet functions for 7 days before sampling. Basal platelet count was assayed. It was $305 \pm 45 \times 10 \%$ Ten $\mathrm{ml}$ of blood were collected under complete aseptic conditions by vacutainer system in 2 plain sterile tubes after adding 750 mid-citrate-dextrose in each tube, then the tubes were centrifuged at $200 \mathrm{~g}$ for 15 minutes (mint). After that, plasma from both tubes was transferred into a new plain sterile tube which was centrifuged again at $1200 \mathrm{~g}$ for $10 \mathrm{~min}$. The supernatant containing platelet poor plasma was discarded keeping only $1 \mathrm{ml}$ of PRP in the bottom 
of the tube. The final platelet count was $1127 \pm 115 \mathrm{x}$ $10^{3} / \propto 1$.

PRP was given in a dose of $0.5 \mathrm{ml} / \mathrm{kg}$ by intra peritoneal injection two days a week, according to Shoeib et al., [20] with some modifications, starting at 8 th week p.i. for 4 weeks.

\section{Experimental design:}

Seventy mice were randomly divided into 5 groups as the following:

Group I: Uninfected control (UC, $\mathrm{n}=10$ ),

Group II: Infected untreated (IU, $n=15$ ),

Group III: Infected, treated with PZQ at 8 th week p.i. (PZQ, $n=15)$,

Group IV: Infected, received PRP at 8 th week p.i. (PRP, $\mathrm{n}=15)$ and

Group V: Infected, treated at 8 th week p.i. with $P Z Q$ then received $P R P(P Z Q+P R P$, $\mathrm{n}=15$ ).

All the mice were euthanized by cervical dislocation at 12 th week p.i. and the blood was collected promptly by heart puncture. It was left at room temperature for $20 \mathrm{~min}$, and then centrifuged at $2000 \mathrm{rpm}$ for $15 \mathrm{~min}$ to collect serum which was stored in aliquots at $-80^{\circ} \mathrm{C}$.

\section{Parasitological parameters: \\ Worm burden:}

After mice sacrificing, adult worms were perfused from liver and portomesenteric vessels and counted according to Duvall and DeWitt [25].

\section{Eggs per gram of infected tissue:}

Small portions of liver and intestine were weighted, left in $5 \% \mathrm{KOH}$ overnight at $37^{\circ} \mathrm{C}$ and mean eggs per gram tissues was calculated [26].

\section{Histopathological analysis:}

Liver portions from the euthanized mice were stained with hematoxylin and eosin (H\& E) following the standard procedure. The specimens were fixed in formalin $10 \%$, and then they were dehydrated in ascending grades of alcohol before washing with xylene. The dehydrated tissues were embedded in molten paraffin wax and then cut into thin sections. The sections were mounted on clean glass slides and stained with H\& E. For each mouse, the mean hepatic granulomas number was assessed in five successive fields at $\mathrm{x} 10$ power field magnification, and the mean granulomas diameter in $\propto \mathrm{m}$ was calculated using ocular micrometer (Olympus, Tokyo, Japan). Only granulomas having a single ovum were taken into consideration.

\section{Masson's trichrome staining of hepatic fibrosis:}

Masson's trichrome-stained liver sections were utilized to estimate hepatic fibrosis. Paraffinized liver samples were stained using Masson's trichrome staining kit (Sigma-Aldrich, St. Louis, USA) following the manufacturer's instructions. The percent of fibrosis was computed by applying the image $\mathrm{J}$ software program, version $1.47 \mathrm{v}$, using photos taken for liver slides of the mice groups.

\section{Immunohistochemistry:}

$\alpha$-SMA, TGF- $(31$, iNOS, and caspase- 3 were estimated, in liver tissues of all mice groups, by the immunohistochemical method using the standard avidin-biotin immunoperoxidase. Briefly, sections from the previously prepared liver paraffin blocks ( $4 \propto \mathrm{m}$ thick) were mounted on glass slides, then kept overnight at $56^{\circ} \mathrm{C}$. The slides were dewaxed in xylene and dehydrated in descending grades of ethanol. The endogenous peroxides activity was blocked by heating the slides at $100{ }^{\circ} \mathrm{C}$ in a microwave oven in 3\% hydrogen peroxide for $15 \mathrm{~min}$, and antigen retrieval was done by incubating the sections in citrate buffer ( $\mathrm{pH}$ 6.0) for another $15 \mathrm{~min}$ in a humid chamber at $22^{\circ} \mathrm{C}$. After that, the slides were incubated overnight at $4{ }^{\circ} \mathrm{C}$ with the corresponding primary antibodies which were diluted in phosphate buffer solution (PBS); rabbit $\alpha$-SMA antibody (Santa Cruz Biotechnology, Heidelberg, Germany, diluted 1:500), rabbit TGF-(31 antibody (Santa Cruz Biotechnology, diluted 1:500), rabbit iNOS antibody (Abcam, Cambridge, UK, diluted 1:100) and rabbit caspase-3 (Abcam, diluted 1:500). After rinsing in PBS, the sections were incubated with biotinylated secondary anti-mouse antibody for $30 \mathrm{~min}$ and after further round of washing with PBS, avidin-biotin complex horseradish peroxidase solution was added for $15 \mathrm{~min}$. The reaction was developed using 3,3' diaminobenzidinetetrahydrochloride (DAB), then the slides were counterstained with Meyer's haematoxylin and mounted. Negative control slides were prepared following the same steps but without adding the primary antibodies. The slides were examined using a Zeiss light microscope.

\section{Evaluation of immunostaining:}

For staining comparison among liver sections of the different mice groups, the samples were scored semiquantitatively using the $\mathrm{H}$-score that considers both the percentage of positive cells and the staining intensity. The percentage of the positive cells were graded on a scale of 0 to $4+(0$ : Negative; $1+:<25 \% ; 2+: 26-50 \% ; 3+: 51-75 \%$ and $4+:>75 \%$ ) and the intensity of the staining was graded as 0 : Negative; 1+: Mild; 2+: Moderate and 3+: Strong. 
Percent of the stained cells in each sample was multiplied by the intensity of staining. A score of 0-300 was given for each measured bio-marker according to the following equation: $\mathrm{H}$ score $=$ $[(\%$ of mild $\times 1)+(\%$ of moderate $\times 2)+(\%$ of strong $x$ 3)] [27]

\section{Biochemical studies:}

Levels of alanine aminotransferase (ALT), aspartate aminotransferase (AST) and alkaline phosphatase (ALP) were assayed in the mice sera using Beckman Coulter Olympus AU480 automated chemistry analyzer (Beckman Instrument. Inc. Fullerton, California USA). The results were expressed as units per liter (U/L).

\section{Statistical data analysis:}

The results were analyzed using the SPSS (Statistical Package for the Social Sciences, version20 for Windows) software (SPSS Inc., Illinois, USA). The values were presented as mean \pm standard deviation (SD). The percentage of reduction (PR) in the treated mice groups $=(\mathrm{C} \mathrm{T} / \mathrm{C}) \times 100$, where $\mathrm{C}$ is mean of a parameter of IU mice group and $\mathrm{T}$ is mean of the treated mice group. Significant differences were determined by one-way analysis of variance (ANOVA) followed by a post-hoc test. $p$-values of less than $0.05,0.01$ or 0.001 were used to indicate statistical significance.

\section{Results}

\section{Parasitological results:}

$\mathrm{PZQ}+\mathrm{PRP}$ and $\mathrm{PZQ}$ regimens significantly reduced $(p<0.001)$ the mean total worm number by $86.5 \%$ and $88.7 \%$, respectively compared to IU mice group. Both treatments results did not differ significantly $(p>0.05)$ from each other. PRP alone did not show any significant decrease $(p>0.05)$ in the mean worm number (6.9\%) in comparison to IU mice group (Table 1).

Regarding the mean egg count per gram tissue, PZQ+PRP and PZQ significantly decreased $(p<0.001)$ the hepatic eggs by $86 \%$ and $85.6 \%$, respectively as well as they significantly decreased $(p<0.001)$ intestinal eggs by $87.8 \%$ and $89.1 \%$, respectively compared to IU mice with insignificant difference $(p>0.05)$ between each other. PRP alone had insignificant effect $(p>0.05)$ on the mean liver $(5.5 \%)$ or intestinal egg $(7.6 \%)$ numbers in comparison to IU mice group (Table 1).

\section{Histopathological H\&E examination results: \\ Histopathological changes:}

Liver sections of UC mice group showed preserved hepatic architecture with intact hepatic cells arranged in columns around a corresponding central vein with no inflammatory cellular infiltration. Liver tissues of IU mice revealed large fibrocellular granulomas consisted of Schistosoma ova surrounded by inflammatory cells, such as lymphocytes, macrophages, eosinophils, epithelioid cells and fibroblasts with thick fibrous area present at periphery of the granuloma. Treatment with $\mathrm{PZQ}+\mathrm{PRP}$ or PZQ changed the granuloma to become more cellular with lower fibrous area than that of IU mice. Also, PRP reduced the fibrous region more than PZQ (Fig. 1).

Measurement of hepatic granuloma numbers and diameters:

PZQ+PRP and PZQ treatments significantly reduced $(p<0.01)$ the mean hepatic granuloma number by $55.9 \%$ and $61.2 \%$, respectively when compared to the IU mice group without significant difference between each other, whereas PRP alone did not significantly reduce $(3.2 \%, p>0.05)$ the mean hepatic granuloma number (3.2\%). Regarding the granuloma diameter, all the treated mice groups showed significant reduction $(p<0.001)$ in the mean diameter, in comparison to IU mice group, and the highest percent of reduction was revealed by $\mathrm{PZQ}+$ PRP $(71 \%)$ followed by PRP (51.2\%) then PZQ $(33.8 \%)$ with a significant difference $(p<0.05)$ between PRP and PZQ (Fig. 2).

Digital image analyzing for percentage of fibrosis:

Masson's trichrome stained the collagen fibers with blue and cells nuclei with black. In IU mice, the collagen fibers were thick and the mean percentage of fibrosis, measured digitally, was $57.2 \%$. All the treatments caused thinner collagen fibers and significantly decreased $(p<0.001)$ the percentage of fibrosis compared to IU mice group. PZQ+PRP revealed the highest reduction in percentage of fibrosis with $73.3 \%$ followed by PRP with $63.8 \%$, but PZQ achieved $50.8 \%$ only (Fig. $3 \mathrm{~A} \& \mathrm{~B})$.

\section{Immunohistochemical results:} ot -SMA:

Liver cut sections of UC mice were negative for $0 \tau-S M A$ immunostaining. Mice infected with $S$. mansoni showed strong cellular expression of or-SMA and the positive cells were mainly distributed at the periphery of and inside the hepatic granuloma. The expression of ot -SMA decreased in a great extent with $\mathrm{PZQ}+\mathrm{PRP}$ administration, where this mice group showed mild expression, and both PRP and PZQ induced moderate expression of or -SMA (Fig. 4A). 
IU mice revealed $175.6 \pm 15.1$ of the mean $\mathrm{H}$ score of $\alpha$-SMA positive cells, and when received treatment, the mean $\mathrm{H}$-score is significantly lowered $(p<0.001)$ among the treated mice groups, where PZQ+PRP induced the lowest mean $\mathrm{H}$-score of $\alpha$ SMA positive cells recording $10.7 \pm 2.1$, followed by PRP with $49.4 \pm 6.3$ that was less than that shown by PZQ (97.2 \pm 8.2$)$. Also, PZQ+PRP significantly reduced the $\mathrm{H}$-score compared to either PRP $(p<0.001)$ or PZQ $(p<0.001)$, while PRP significantly reduced $(p<0.01)$ the $\mathrm{H}$-score compared to PZQ treated mice (Fig. 4B).

TGF- $\beta$ 1:

Liver specimens of UC mice were negative for TGF- $\beta 1$ on immunohistochemistry study. In mice infected with the parasite (IU), strong positively stained TGF- $\beta 1$ cells were found surrounding and infiltrating the granulomas (fibroblasts and inflammatory cells), beside their presence in the liver parenchyma (hepatocytes). PZQ+PRP regimen decreased the immunoreactivity of TGF- $\beta 1$ leading to mild expression of the cytokine and both PRP and PZQ resulted in moderate TGF- $\beta 1$ expression (Fig. 5A).

The mean $\mathrm{H}$-score of TGF- $\beta 1$ positive cells in the IU mice group recorded $130.6 \pm 17.1$ and all treatment regimens significantly lowered $(p<0.001)$ that score comparing to IU, where PZQ+PRP induced the lowest mean $\mathrm{H}$-score with $6.5 \pm 1.3$, followed by PRP ( $31.5 \pm 6.5)$, then PZQ $(69.4 \pm 7.2)$. $\mathrm{PZQ}+\mathrm{PRP}$ significantly reduced the $\mathrm{H}$-score compared to either PRP $(p<0.01)$ or PZQ $(p<0.001)$, while PRP significantly reduced $(p<0.01)$ the $\mathrm{H}-$ score compared to PZQ treated mice (Fig. 5B).

iNOS:

The liver sections of UC mice were negative for iNOS monoclonal antibodies. The infected untreated mice showed strong immunohistochemical reactivity of iNOS and this was more at the periphery of the granuloma and intra-granulomatous in comparing to the treated mice groups. PZQ+PRP caused the lowest expression of iNOS which was mild expression. Both PRP and PZQ induced moderate reactivity of iNOS in the cytoplasm of the active cells (Fig. 6A).

The IU mice recorded $205.7 \pm 15.1$ of the mean $\mathrm{H}$-score of positive cells for iNOS. PZQ+PRP induced the lowest mean $\mathrm{H}$-score of iNOS expressing cells by $30.8 \pm 5.9$, followed by PRP which achieved 77.4 \pm 10.3 , but PZQ revealed 142.3 \pm 9.3 . $\mathrm{PZQ}+\mathrm{PRP}$ significantly reduced the H-score compared to either PRP $(p<0.01)$ or PZQ $(p<0.001)$, while PRP significantly reduced $(p<0.01)$ the $\mathrm{H}$ score compared to PZQ treated mice (Fig. 6B).

\section{Caspase-3:}

Livers of UC mice were negative for caspase3 , while those of IU mice revealed mild immunohistochemical reactivity at the periphery of the granuloma. $\mathrm{PZQ}+\mathrm{PRP}$ caused strong expression of caspase-3, whereas both PRP and PZQ induced moderate reactivity of caspase-3 (Fig. 7A).

On computing mean $\mathrm{H}$-score of caspase- 3 positive cells, IU mice recorded 23.3 \pm 4.3 . PZQ+PRP induced the highest significant $(p<0.001)$ increase of mean $\mathrm{H}$-score of caspase- 3 expressing cells by 105.8 \pm 3.9 , followed by PRP which induced $65.4 \pm$ $2.3(p<0.001)$, but PZQ revealed $42.1 \pm 3.1(p<0.05)$ compared to IU mice group. PZQ+PRP significantly reduced the $\mathrm{H}$-score compared to either PRP $(p<0.001)$ or PZQ $(p<0.001)$, while PRP significantly reduced $(p<0.01)$ the $\mathrm{H}$-score compared to PZQ treated mice (Fig. 7B).

Table (1): Effects of PRP alone or in combination with PZQ on worm burden and ova count/g tissue in $S$. mansoni infected mice.

\begin{tabular}{|c|c|c|c|c|c|c|}
\hline \multirow[b]{2}{*}{ Mice groups } & \multicolumn{2}{|l|}{$\begin{array}{l}\text { Worm burden } \\
(\text { mean } \pm \text { SD) }\end{array}$} & \multicolumn{4}{|l|}{$\begin{array}{l}\text { Ova count/g } \\
(\text { mean } \pm \text { SD) }\end{array}$} \\
\hline & No. & PR & Liver & PR & Intestine & PR \\
\hline IU & $23.1 \pm 4.3$ & & $18170 \pm 3706$ & & $21125 \pm 5632$ & \\
\hline PZQ & $2.6 \pm 1.1 * * *$ & $88.7 \%$ & $2606 \pm 304 * * *$ & $85.6 \%$ & $2295 \pm 278 * * *$ & $89.1 \%$ \\
\hline PRP & $21.5 \pm 3.2 \# \# \#$ & $6.9 \%$ & $17161 \pm 3510 \# \# \#$ & $5.5 \%$ & 19515士4612\#\#\# & $7.6 \%$ \\
\hline PZQ+PRP & $3.1 \pm 0.3 * * * \dagger+\dagger$ & $86.5 \%$ & $2530 \pm 332 * * * \dagger+\dagger$ & $86 \%$ & $2572 \pm 306 * * * \dagger+\dagger$ & $87.8 \%$ \\
\hline
\end{tabular}

Results are presented as mean \pm SD for each mice group. $* * * p<0.001$, indicates statistical significant difference from IU mice group; \#\#\# $<<0.001$, indicates statistical significant difference from PZQ treated mice group and $\dagger \dagger \dagger p<0.001$, indicates statistical significant difference from PRP treated mice group using one-way ANOVA followed by a post-hoc test. $\mathrm{PR}=$ percent of reduction. 
a 90 in a

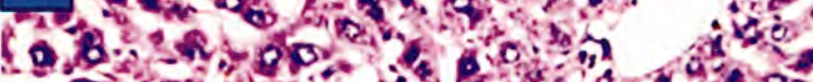

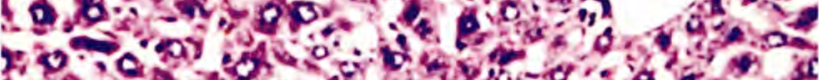

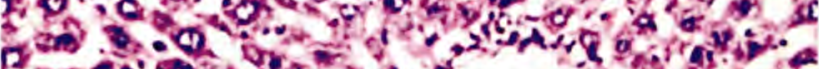

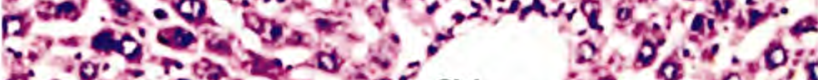
o

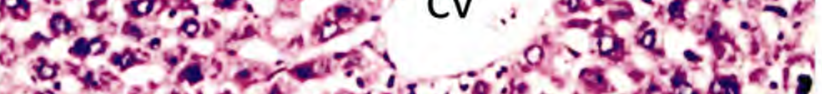
or 8 ;

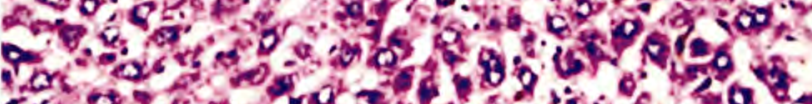
$500+3 x$.

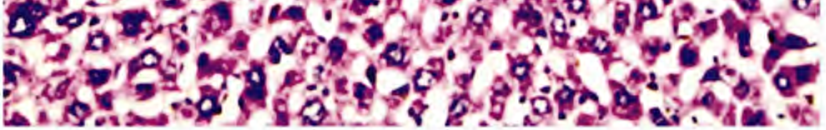
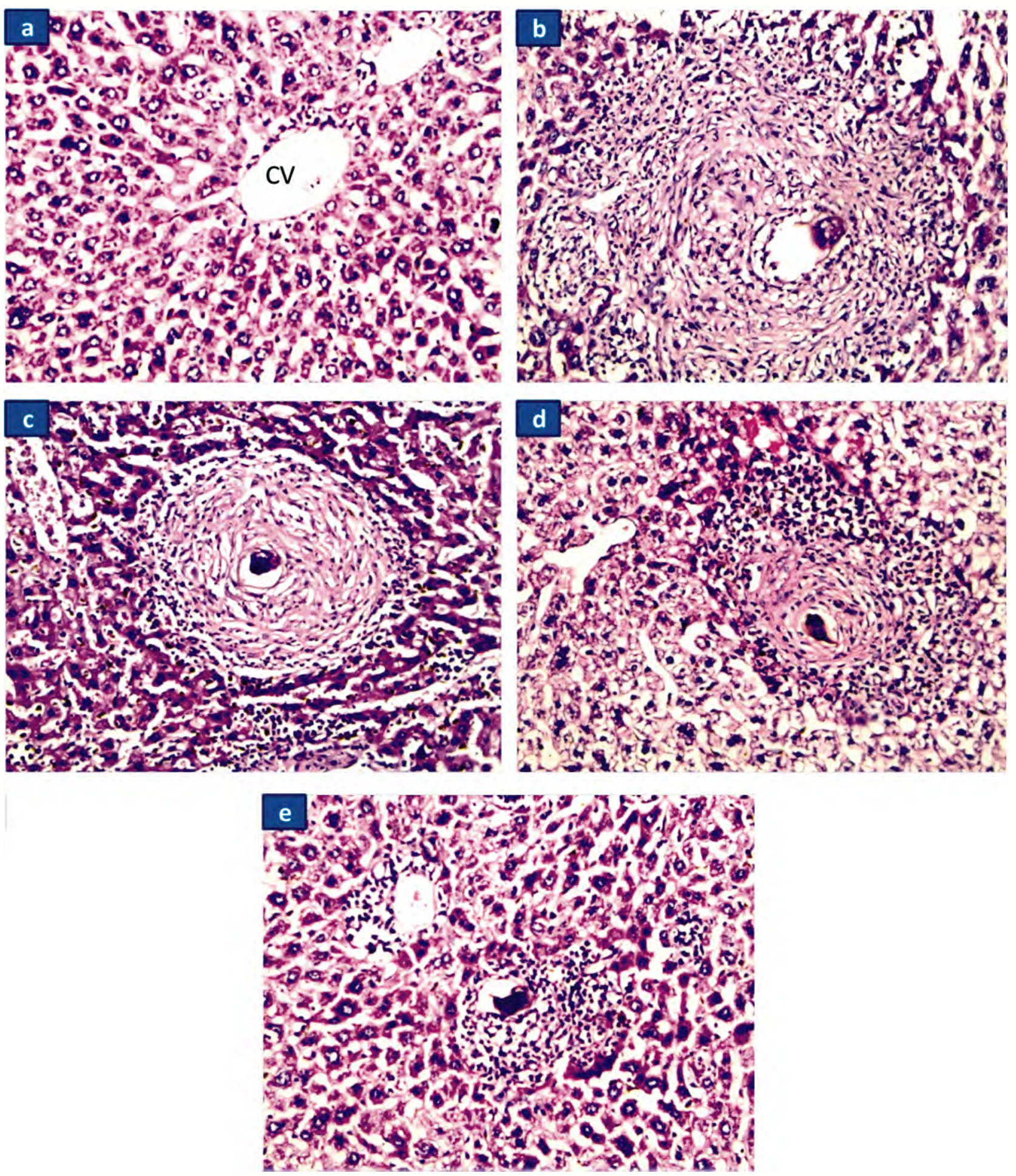

Fig. (1): Representative photomicrographs of the pathological changes in liver tissues stained with H\& E (x200). (A): UC mice showing normal hepatic architecture with central vein (CV) and the hepatic cells arranged in cords; (B): IU mice revealing large-sized S. mansoni granuloma containing central ova surrounded by chronic inflammatory cells; (C): PZQ treated mice showing smaller granuloma than in IU mice which has more cellular content; (D): PRP treated mice showing granuloma that is smaller in size than in PZQ treated mice group and (E): PZQ+PRP treated mice showing the smallest granuloma among the treated mice groups. 

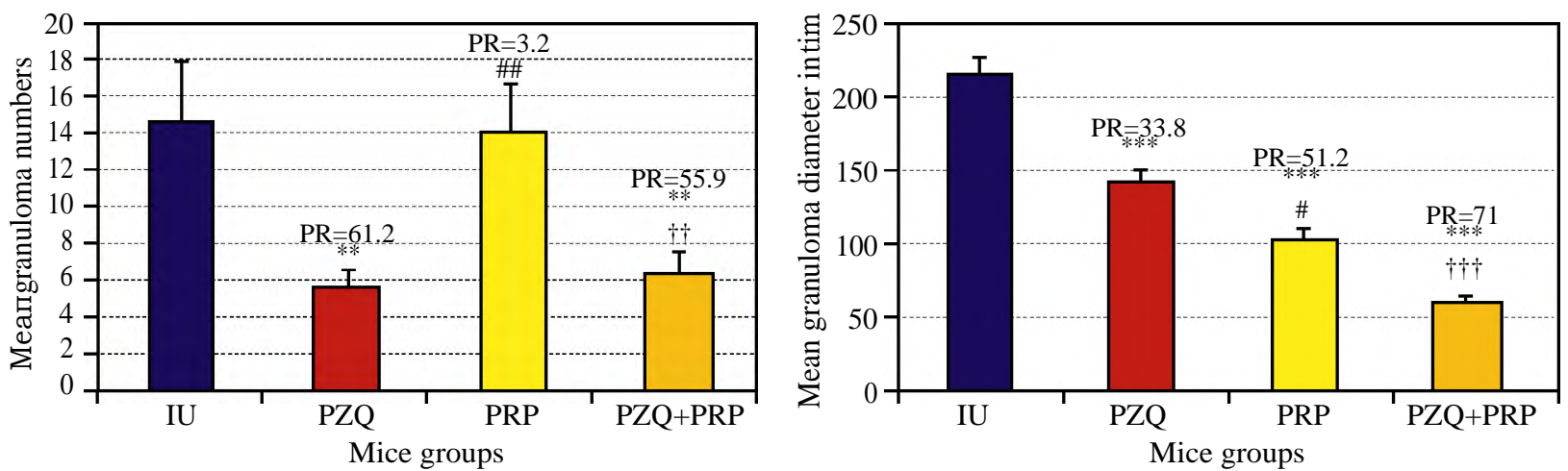

Fig. (2): Effects of PRP alone or in combination with PZQ on mean hepatic granuloma number and diameter of S. mansoni infected mice. Results are presented as mean \pm SD for each mice group. $* * * p<0.001$ and $* * p<0.01$ indicate statistical significant difference from IU mice group; \#\#p<0.01 and \#p<0.05 indicate statistical significant difference from PZQ treated mice group and $\dagger \dagger \dagger p<0.001$ and $\dagger \dagger p<0.01$ indicate statistical significant difference from PRP treated mice group using one-way ANOVA followed by a post-hoc test. $\mathrm{PR}=$ percent of reduction.

(A)
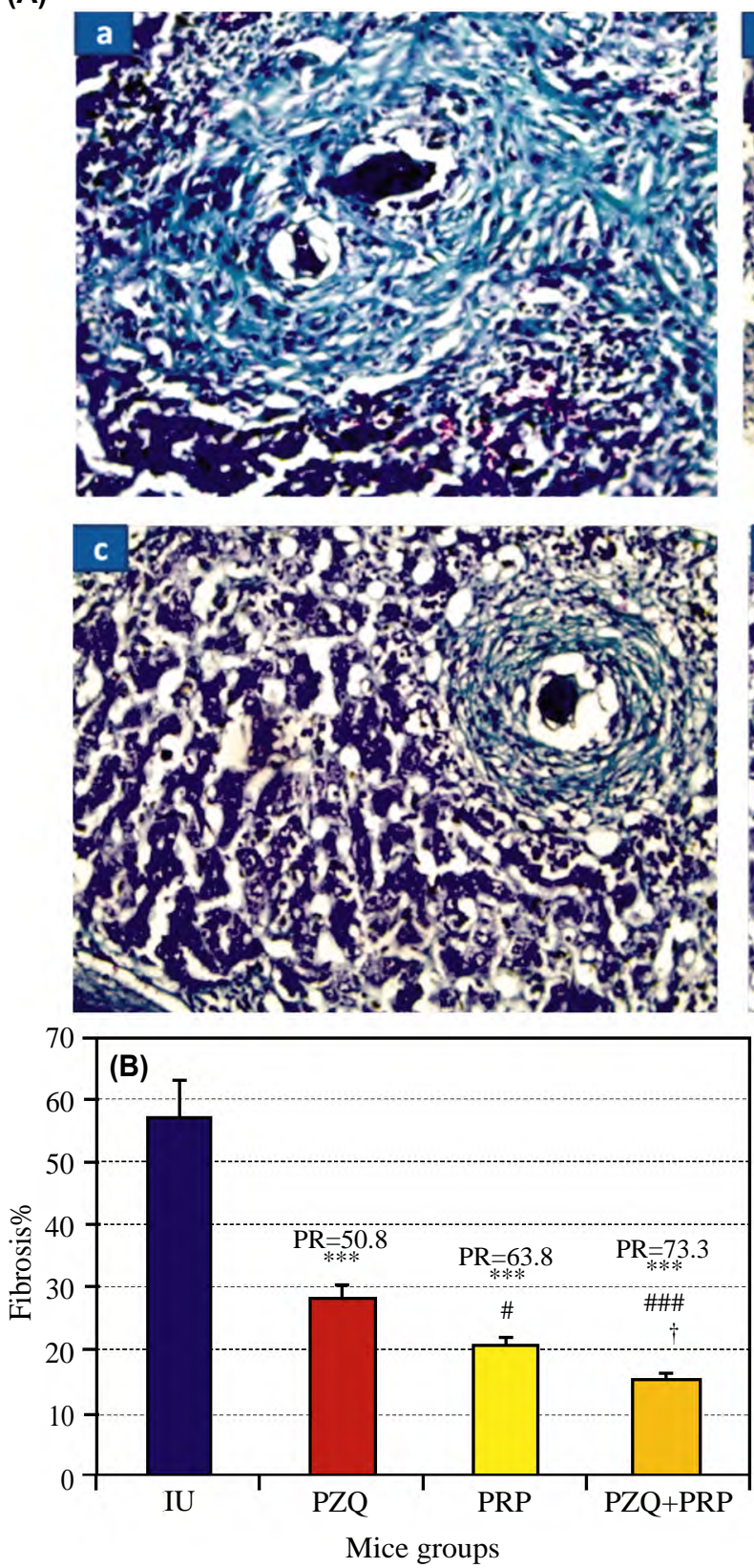
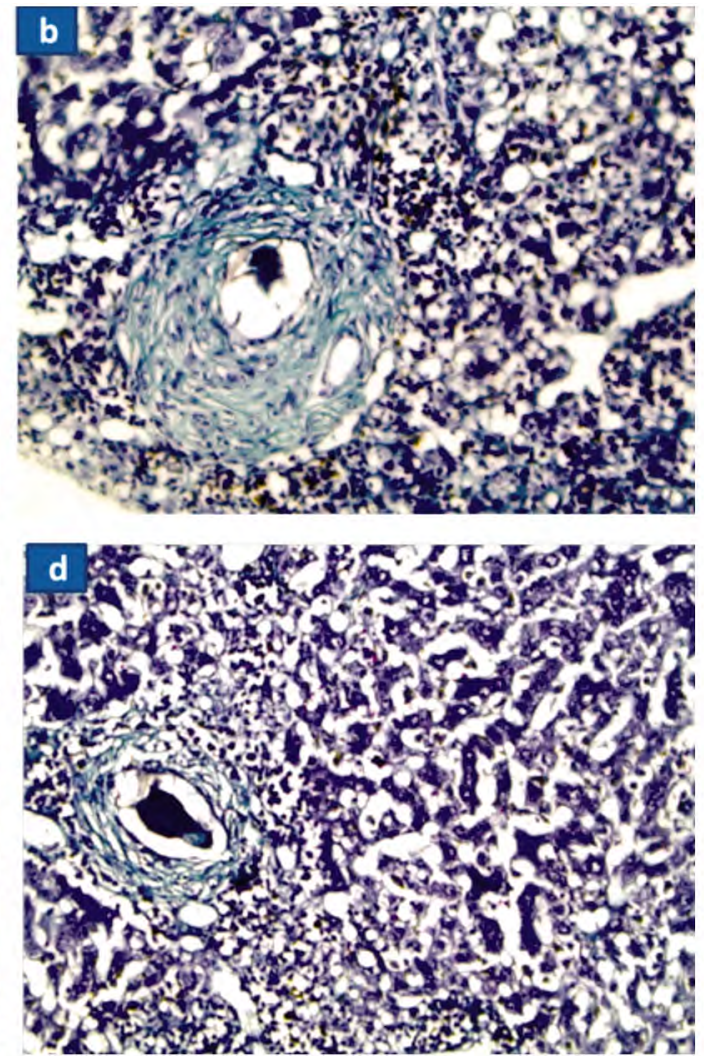

Fig. (3): (A) Representative photomicrographs of Masson's trichrome stain of liver fibrosis (x 200). (a): IU mice showing large sized granuloma with excessive collagen depositions which decreased gradually in thickness and contents in PZQ treated mice (b), PRP treated mice (c) and PZQ+PRP treated mice (d) which revealed the best result. (B) The percentage of liver fibrosis calculated by image $\mathbf{J}$ software program. Results are presented as mean \pm SD for each mice group. $* * * p<0.001$ indicates statistical significant difference from IU mice group; \#\#\# $p<0.001$ and $\# p<0.05$ indicate statistical significant difference from PZQ treated mice group and $\dagger p<0.05$ indicates statistical significant difference from PRP treated mice group using one-way ANOVA followed by a post-hoc test. PR=Percent of reduction. 
(A)
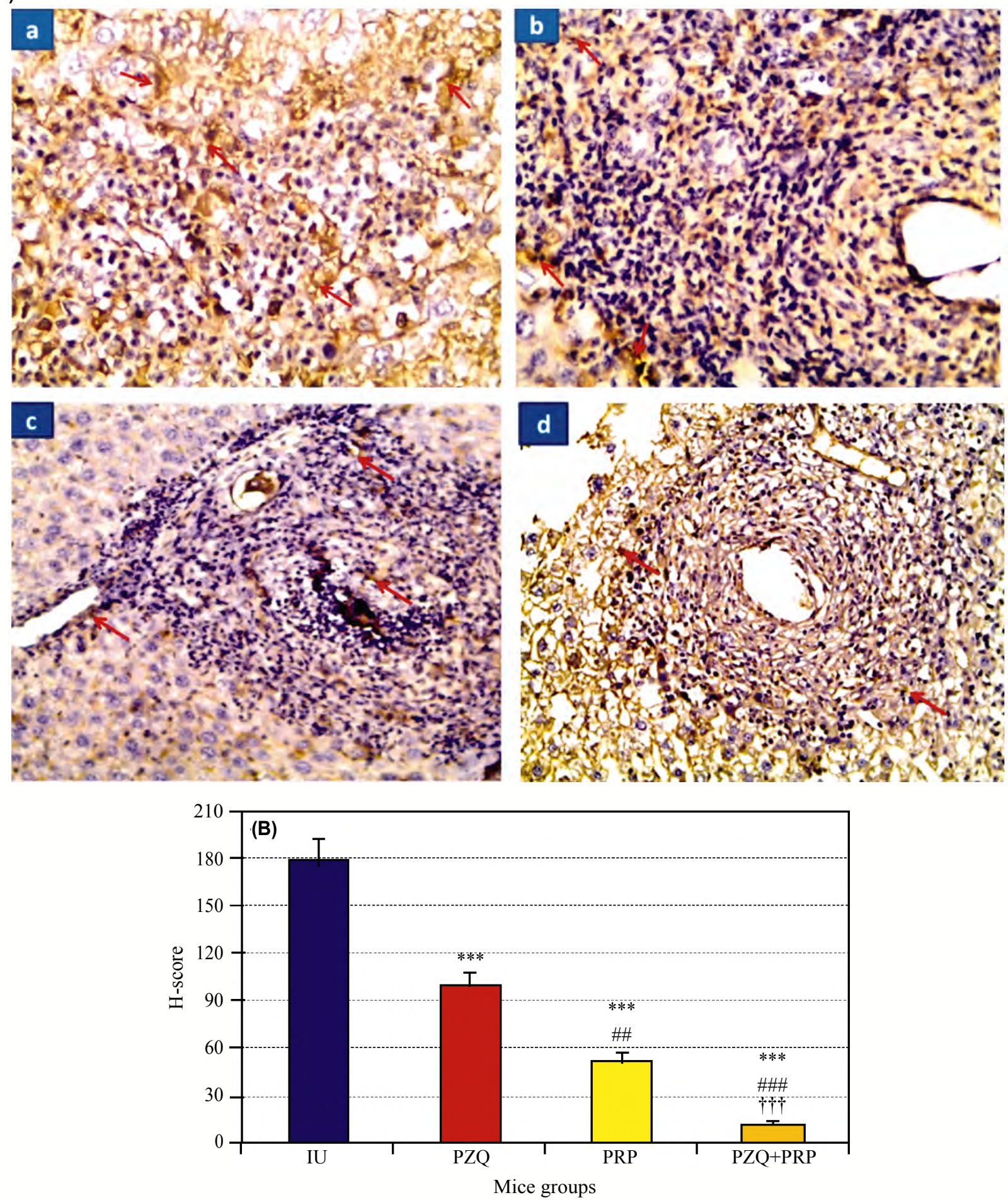

Fig. (4): (A) Representative photomicrographs of $\alpha$-SMA immunostaining in the liver tissues. (a): IU mice showing strong positively stained $\alpha$-SMA cells found intra-granulomatous (x400); (b): PZQ treated mice showing moderate positively stained $\alpha$-SMA cells found intra-granulomatous and around the granuloma (x400); (c): PRP treated mice showing moderate positively stained $\alpha$-SMA cells with less number cells than in PZQ treated mice (x200) and (d): PZQ+PRP treated mice showing mild positively stained $\alpha$-SMA cells (x200). Red arrows point to the positive cells. (B) The H-score of $\alpha$-SMA positive cells. Results are presented as mean \pm SD for each mice group. $* * * p<0.001$ indicates statistical significant difference from IU mice group; $\# \# \# p<0.001$ and $\# \# p<0.01$ indicate statistical significant difference from PZQ treated mice group and $\dagger \dagger \uparrow p<0.001$ indicates statistical significant difference from PRP treated mice group using one-way ANOVA followed by a post-hoc test. 
(A)
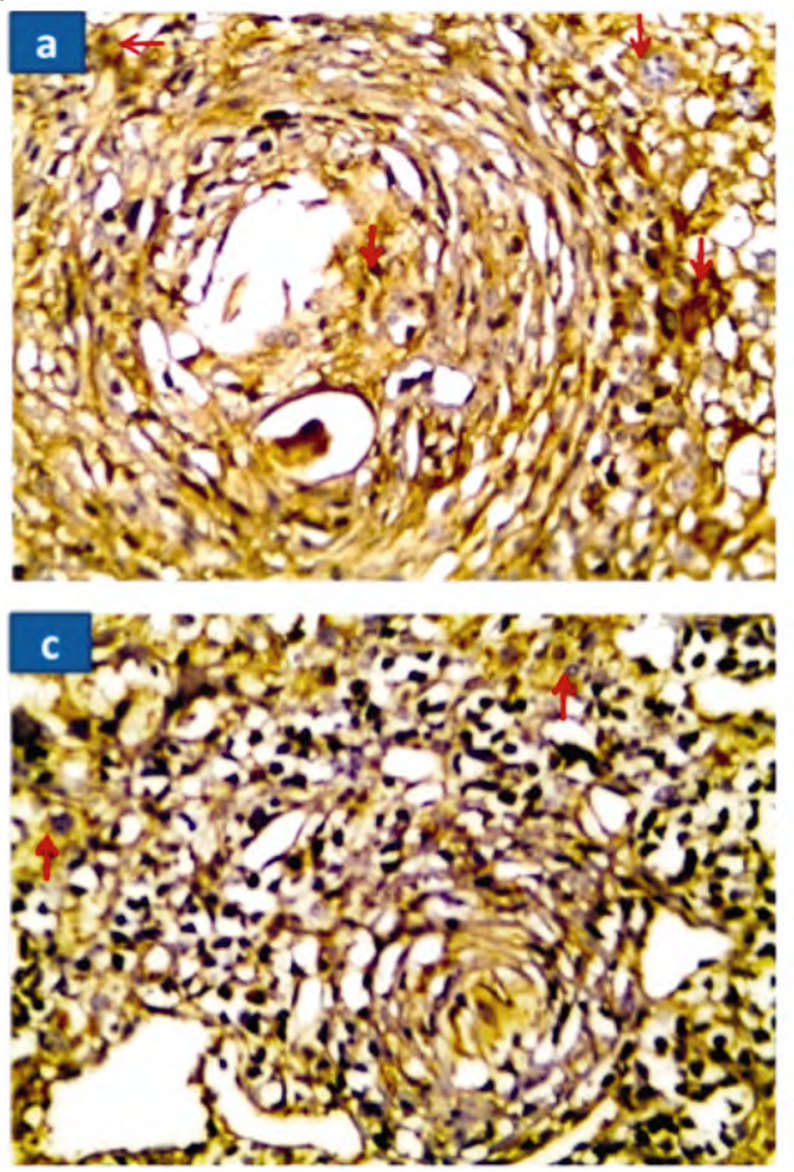
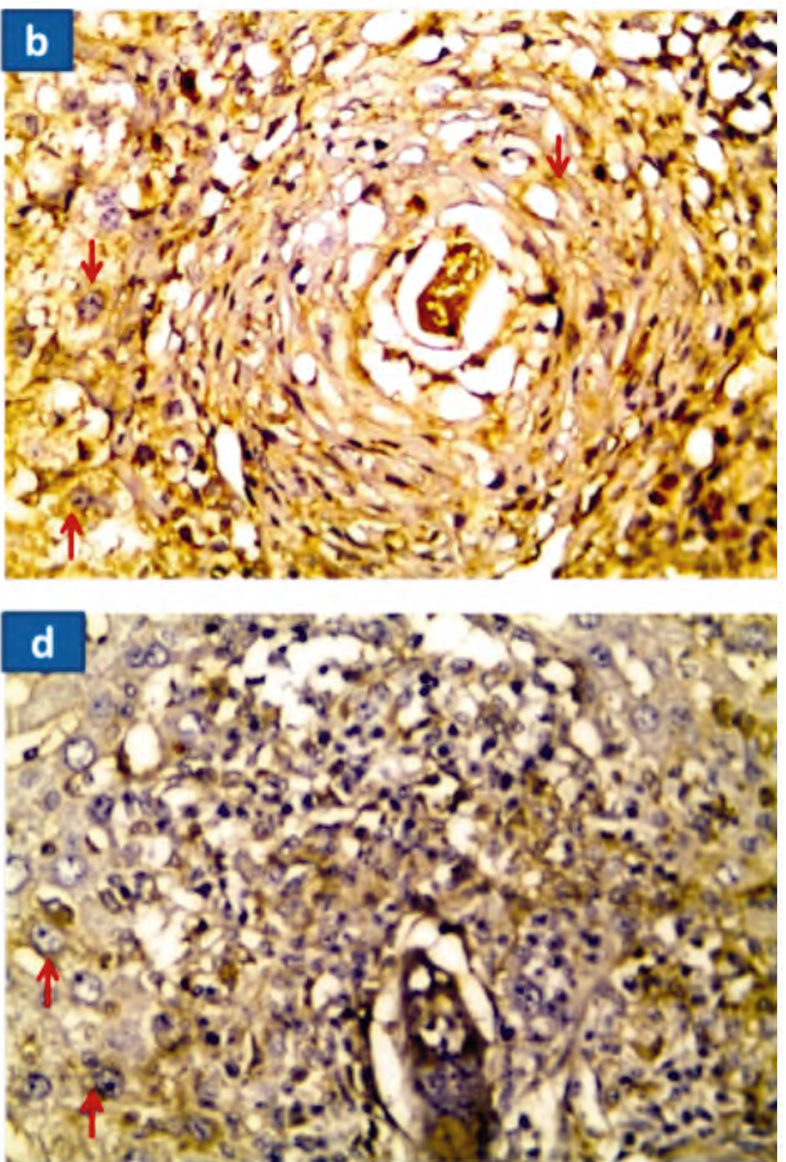

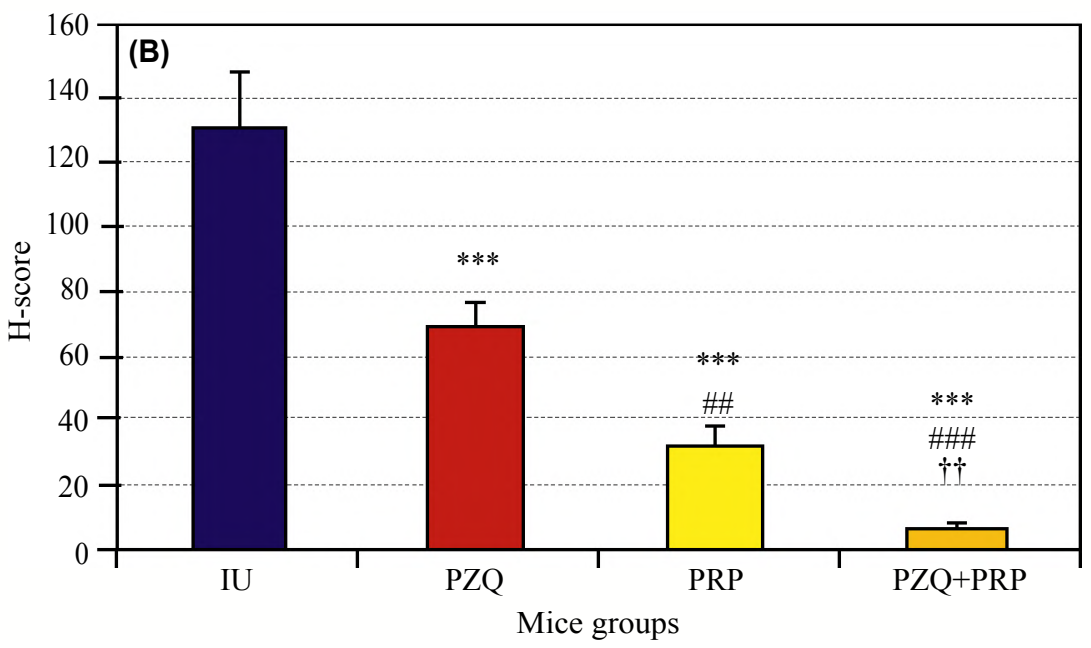

Fig. (5): (A) Representative photomicrographs of TGF-(3 1 immunostaining in the liver tissues (x400). (a) IU mice showing strong TGF-(3 1 immunoreactivity where the positive cells were mainly hepatocytes surrounding granulomas, in addition to the fibroblasts with chronic inflammatory cells found around and inside the granuloma; (b) PZQ treated mice showing moderate TGF-(3 1 immunoreactivity; (c): PRP treated mice showing moderate positively stained TGF-( 1 cells and (d) PZQ+PRP treated mice showing mild TGF-(3 1 immunoreactivity having the least number of positive cells among the treated mice groups. Red arrows point to the positive cells. (B) The H-score of TGF-( 31 positive cells. Results are presented as mean \pm SD for each mice group. ${ }^{* * *} p<0.001$ indicates statistical significant difference from IU mice group; \#\#\# $p<0.001$ and \#\#p<0.01 indicate statistical significant difference from PZQ treated mice group and $\uparrow \uparrow p<0.01$ indicates statistical significant difference from PRP treated mice group using one-way ANOVA followed by a post-hoc test. 
(A)
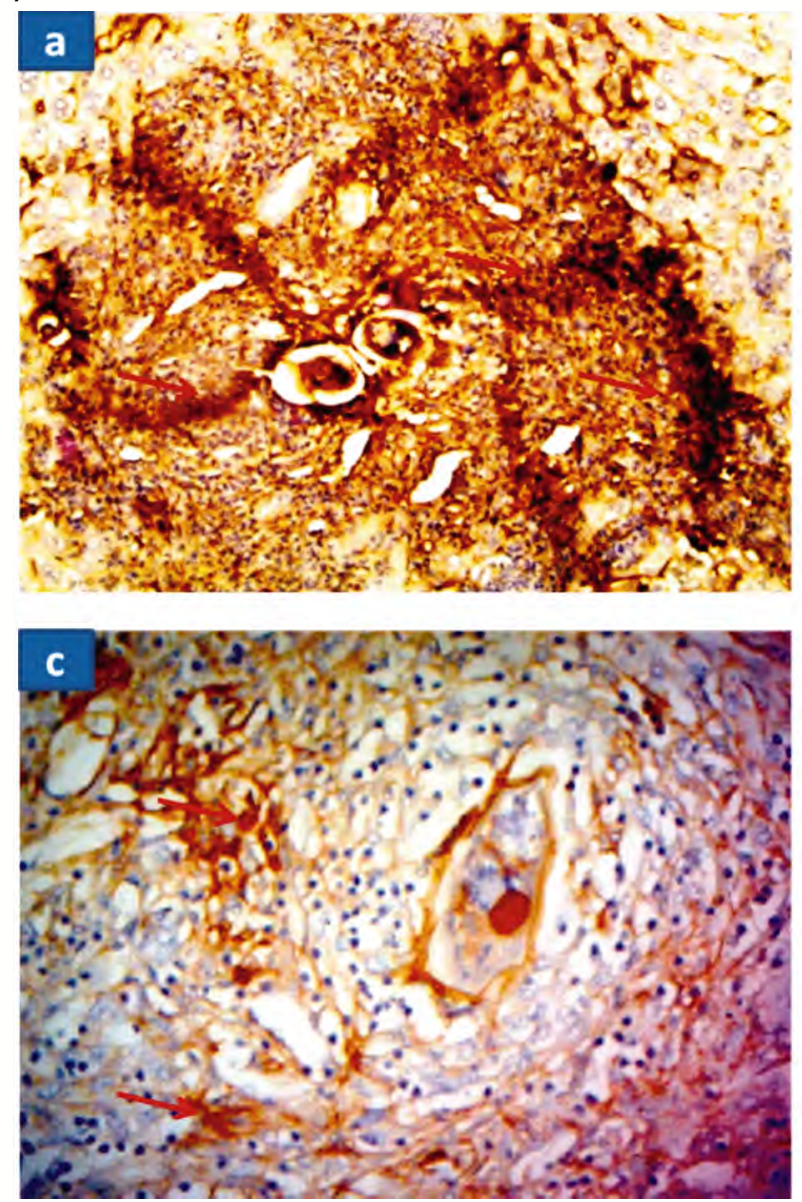
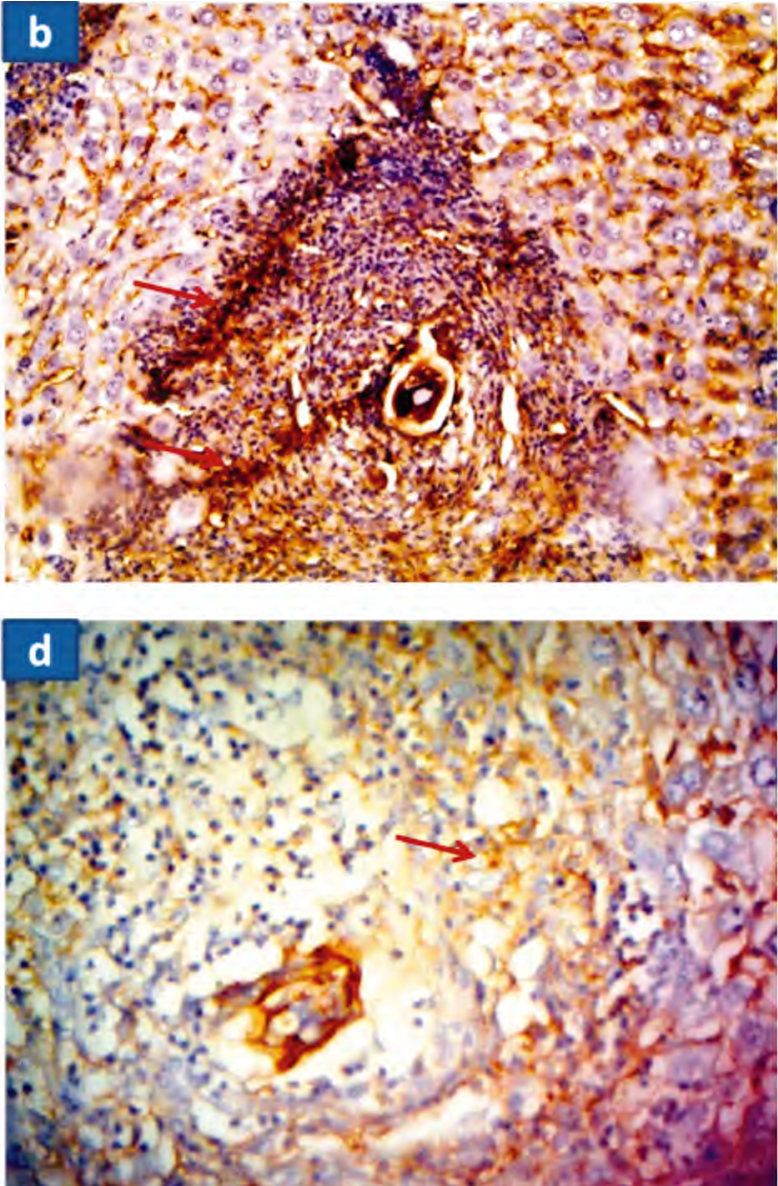

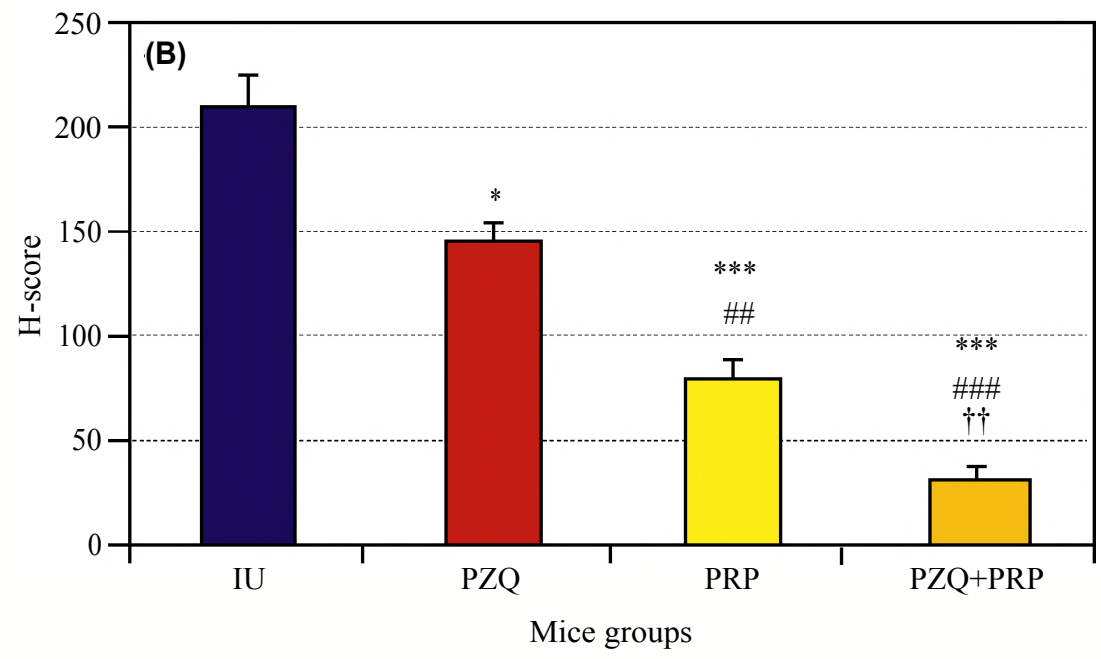

Fig. (6): (A) Representative photomicrographs of iNOS immunostaining in the liver tissues. (a): IU mice showing strong iNOS immunoreactivity mainly inside and around the granuloma (x200); (b): PZQ treated mice showing moderate iNOS immunoreactivity (x200); (c): PRP treated mice showing moderate positively stained iNOS cells (x400) and (d): PZQ+PRP treated mice revealing mild iNOS immunoreactivity with the least number of positive cells among the treated mice groups (x400). Red arrows point to the positive cells. (B) The H-score of iNOS positive cells. Results are presented as mean \pm SD for each mice group. $* * * p<0.001$ and $* p<0.05$ indicate statistical significant difference from IU mice group; \#\#\#p<0.001 and $\# \# p<0.01$ indicate statistical significant difference from PZQ treated mice group and $\uparrow \dagger p<0.01$ indicates statistical significant difference from PRP treated mice group using one-way ANOVA followed by a post-hoc test. 
(A)
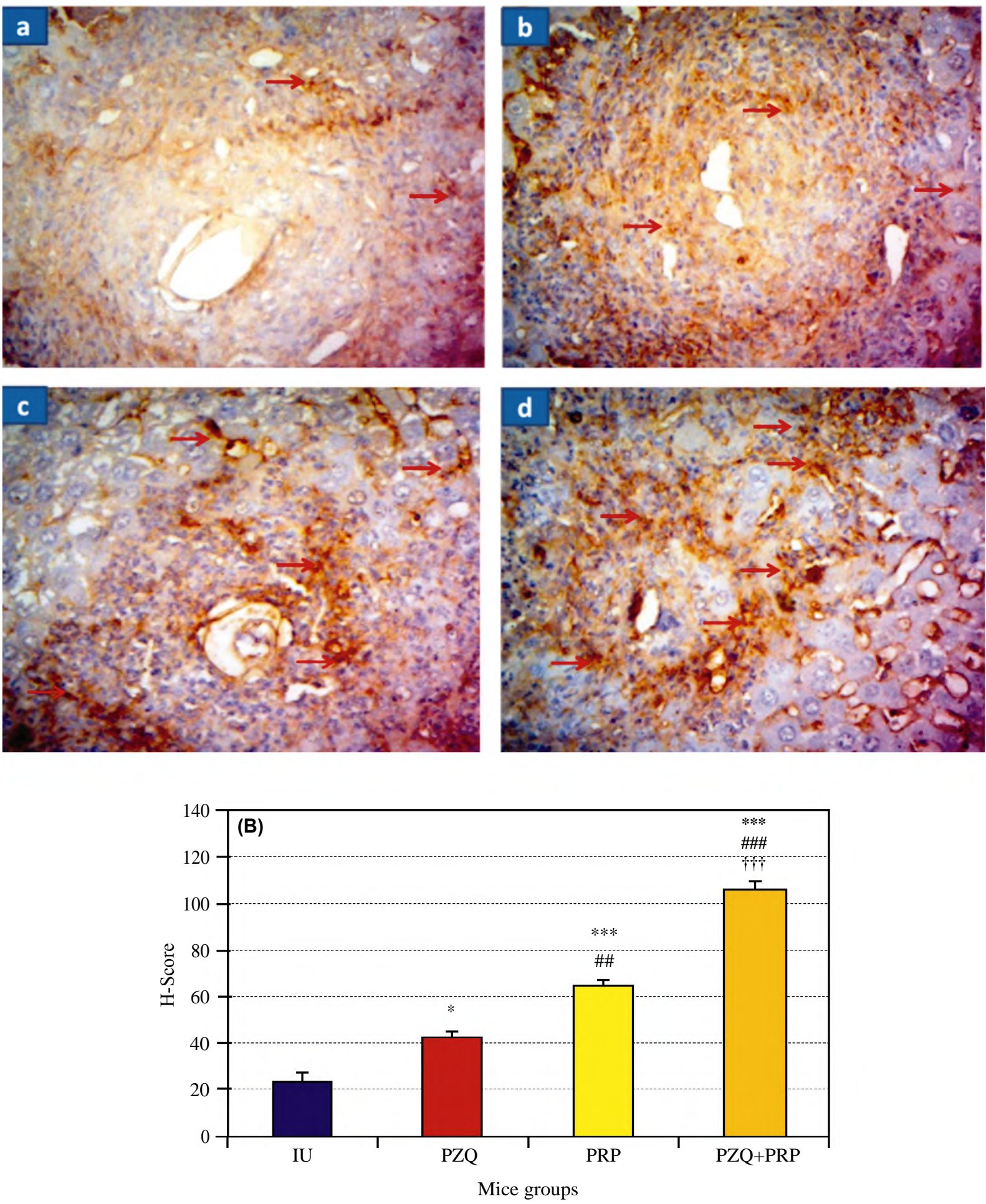

Fig. (7): (A) Representative photomicrographs of caspase-3 immunostaining in the liver tissues. (a): IU mice showing few mild positively stained caspase-3 cells (x200); (b): PZQ treated mice showing moderate positively stained caspase-3 cells with higher cell numbers than IU(x200); (c): PRP treated mice showing moderate positively stained caspase-3 cells (x400) and (d): PZQ+PRP treated mice showing strong caspase-3 immunoreactivity with the highest number of the positive cells among mice groups (x400). Red arrows point to the positive cells. (B) The H-score of caspase-3 positive cells. Results are presented as mean \pm SD for each mice group. $* * * p<0.001$ and $* p<0.05$ indicate statistical significant difference from IU mice group; \#\# $p<0.001$ and \#\#p<0.01 indicate statistical significant difference from PZQ treated mice group and $\dagger \dagger \dagger p<0.001$ indicates statistical significant difference from PRP treated mice group using one-way ANOVA followed by a post-hoc test. 


\section{Liver serum enzymes:}

$S$. mansoni infection (IU mice) showed significant $(p<0.001)$ higher serum levels of ALT $(157 \pm 11.5 \mathrm{U} / \mathrm{L})$, AST $(220.8 \pm 15.5 \mathrm{U} / \mathrm{L})$ and ALP $(82.2 \pm 8.5 \mathrm{U} / \mathrm{L})$ compared to $\mathrm{UC}$ which recorded $30 \pm 4.2,55 \pm 4.5$ and $21.7 \pm 1.2 \mathrm{U} / \mathrm{L}$, respectively. All the treatments significantly reduced hepatic enzymes, and the highest improvement was ach- ieved by PZQ+PRP where, ALT, AST and ALP decreased by $69.2 \%, 65.7 \%$ and $61.1 \%$ respectively. PRP reduced ALT, AST and ALP by $36.2 \%, 42.9 \%$ and $48.1 \%$ respectively, whereas PZQ achieved $38.7 \%, 39.6 \%$ and $44.7 \%$ reduction regarding ALT, AST and ALP respectively in comparison to IU. There was no significant difference between PRP and PZQ concerning levels of the serum enzymes (Table 2).

Table (2): Effect of PRP alone or in combination with PZQ on the liver enzymes ALT, AST and ALP in S. mansoni infected mice.

\begin{tabular}{|c|c|c|c|c|c|c|}
\hline & ALT & & AST & & ALP & \\
\hline Mice groups & $\mathrm{U} / \mathrm{L}$ & PR & $\mathrm{U} / \mathrm{L}$ & PR & $\mathrm{U} / \mathrm{L}$ & PR \\
\hline UC & $30.8 \pm 4.2$ & & $55 \pm 4.5$ & & $21.7 \pm 1.2$ & \\
\hline IU & $157.5 \pm 11.5 \& \& \&$ & & $220.8 \pm 15.5 \& \& \&$ & & $82.2 \pm 8.5 \& \& \&$ & \\
\hline PZQ & $96.5 \pm 5.3 \& \& * *$ & 38.7 & $133.3 \pm 9.7 \& \& \& * * *$ & 39.6 & $45.4 \pm 3.3 \& \& * *$ & 44.7 \\
\hline PRP & $100.4 \pm 3.2 \& \& * *$ & 36.2 & $126.06 \pm 8.6 \& \& \& * * *$ & 42.9 & $42.6 \pm 2.1 \& \& * *$ & 48.1 \\
\hline PZQ+PRP & $48.5 \pm 3.1 \& * * * \# \# \# \dagger \dagger \dagger$ & 69.2 & $75.7 \pm 3.9 \& * * * \# \# \dagger \dagger$ & 65.7 & $31.9 \pm 1.1 \& * * * \# \dagger$ & 61.1 \\
\hline
\end{tabular}

Results are presented as mean \pm SD for each mice group. $\& \& \& p<0.001, \& \& p<0.01$ and $\& p<0.05$ indicate statistical significant difference from UC mice group. $* * * p<0.001$ and $* * p<0.01$ indicate statistical significant difference from IU mice group; $\# \# \# p<0.001, \# \# p<0.01 \& \# p<0.05$ indicate statistical significant difference from PZQ treated mice group and $\dagger \dagger \dagger p<0.001$ $\dagger \dagger p<0.01 \& \dagger p<0.05$ indicate statistical significant difference from PRP treated mice group using one-way ANOVA followed by a post-hoc test. $P R=$ percent of reduction.

\section{Discussion}

Schistosome's eggs secret many soluble antigens which induce granuloma formation with activation of neighboring HSCs, promoting liver fibrosis $[4,6]$. Yet, there is no accessible effective anti-fibrotic therapy [28]. Recently, PRP has reduced chemically-induced liver fibrosis in experimental animals [19-21]. The aim of this study was to evaluate efficacy of PRP in diminishing liver fibrosis in murine schistosomiasis.

Here, PRP did not influence total worm burden or egg numbers because PRP did not reveal any anti-helminthic or anti-fecundity actions on $S$. mansoni. In spite of PRP did not significantly affect mean hepatic granuloma number, it caused significant reduction in mean hepatic granuloma diameter in comparison with both IU and PZQ and when it was combined with PZQ, the PZQ+PRP treatment caused the most noticeable decrease regarding granuloma diameter. Reducing effect of PRP on the granuloma diameter could be attributed to its anti-fibrotic action as appeared in this study, besides it may induce secretion of some mediators that can regulate granuloma size.

The impact of PZQ on the hepatic granuloma was nearly similar to other workers who have used the same PZQ regimen [29-30]. Praziquantel effect was previously explained by its effect on immune system of the host following destruction of the adult worms leading to bringing down $\mathrm{CD} 4+\mathrm{T}$ and expanding CD8+T cells that result in diminution of the granuloma size [31]

The PZQ+PRP regimen achieved the highest reduction in fibrosis with $73.3 \%$, followed by PRP which revealed $63.8 \%$ and this was superior to PZQ $(50.8 \%)$ compared to IU mice. This PRP antifibrotic effect is in accordance with Watanabe et al., [32] who demonstrated that thrombocytosis, actuated with thrombopoietin or splenectomy, significantly diminished fibrotic area and hepatic hydroxyproline in carbon tetrachloride (CCl4) induced hepatic fibrosis. Also, Takahashi et al., [19] found that human PRP lessened significantly the fibrotic index and hepatic hydroxyproline content in CCl4-initiated liver fibrosis in severe combined immunodeficiency mice. Moreover, a recent study revealed that rat PRP markedly improved dimethylnitrosamine induced liver fibrosis as demonstrated by significant bringing down of liver hydroxyproline content [21]

Concerning PZQ anti-fibrotic result, here, it achieved $50.8 \%$ reduction of fibrosis that was in parallel with Sobhy et al., [29] who utilized the same PZQ dosage as in our study, where fibrosis area is reduced with $56.2 \%$, but it was lower than that recorded by Abd El-Aal et al., [33] who reported $69.2 \%$ reduction in the fibrosis and this difference 
because Abd El-Aal and his colleagues used PZQ for longer period; $300 \mathrm{mg} / \mathrm{kg} / 12 \mathrm{hrs}$ for 30 days. The anti-fibrotic action of PZQ is attributed to killing Schistosoma worms with subsequent decrease in egg numbers and lowering inflammatory responses in association with alternation of several Th1/Th2 cytokines that are engaged with the fibrosis [34].

Herein, it was found that IU mice showed strong expression of $\alpha$-SMA, TGF-(3 1 and iNOS mainly around and in the hepatic granuloma with high $\mathrm{H}-$ score in comparing to the control mice group and this was in agreeing with others $[\mathbf{3 3}, \mathbf{3 5}, \mathbf{3 6}]$. Whereas, caspase- 3 was of mild expression with low $\mathrm{H}$-score in comparison to UC mice group and this is as per Abd El-Aal et al., [33] .

In the present study, $\mathrm{PZQ}+\mathrm{PRP}$ regimen caused the least expression of $\alpha$-SMA, TGF-(3 1 and iNOS with the lowest mean $\mathrm{H}$-score of the positive cells among all the treated mice groups, while either PRP or PZQ achieved moderate expression, but PRP revealed lower $\mathrm{H}$-score than PZQ. On the other side, $\mathrm{PZQ}+\mathrm{PRP}$ induced strong caspase-3 expression with the highest $\mathrm{H}$-score among the treated mice groups, and PZQ and PRP caused moderate caspase-3 expression, but PRP achieved higher $\mathrm{H}$-score than PZQ.

It is well known that $\alpha$-SMA protein is a sensitive marker for the activated HSCs [37]. Reducing $\alpha$-SMA by PRP is in accordance with Takahashi et al., [19] and Salem et al., [21]. The diminishing HSCs activity by PRP could be due to their high content of adenosine triphosphate (ATP) and adenosine diphosphate (ADP) which are released upon their contact with the mice hepatocytes, and then they were degraded by HSCs giving adenosine which increases cyclic adenosine monophosphate (cAMP) inside HSCs hence HSCs inactivation [38]

TGF-( 1 is the primary fibrogenic cytokine that stimulates HSCs activation and it has an important role in the pathogenesis of schistosomiasis fibrosis [7]. Also, it mediates tissue inhibitor metalloproteinases (TIMPs) synthesis and inhibits production of matrix metalloproteinases (MMPs) breaking down extracellular matrix proteins [39]. TGF-( 31 is produced by hepatocytes, Kupffer cells and activated HSCs [40]. The down-regulation of TGF- $(31$ by PRP is in parallel with Watanabe et al., [32], Takahashi et al., [19] and Salem et al., [21], and this could result from increasing hepatocyte growth factor (HGF) production in the mice liver [32] which in turn reduces TGF- $(3$ production during hepatic fibrosis [41].
In the current study, iNOS was estimated as an indirect indicator for NO. The reversal of oxidative stress by PRP as demonstrated by reducing iNOS expression may result in inhibition of HSCs. Oxidative stress may promote proliferation and proinflammatory functions of HSCs [42]. Inhibitors of iNOS have suppressed Schistosoma hepatic fibrosis through changing Th2 cytokines. Besides, NO has a vascular relaxing action leading to increment of blood flow with low inflammatory cells infiltration [43].

Administered PRP has been doucmented to suppress the oxidative stress in other experimental models. Novokmet et al., [44] reported that NO level is significantly decreased in heart of guineapig given PRP. Osterman et al., [45] stated that PRP caused significant lowering of $\mathrm{NO}$ production upon their in-vitro co-culture with cartilage and synovium driven from osteoarthritic patients. PRP lowered $\mathrm{NO}$ level during ischemia-reperfusion injury in an axial pattern flap in mice [46]. In a recent study, PRP of rat significantly decreased the hepatic peroxinitrite level in the rats experimentally administered with thioacetamide (TAA), an inducer of liver damage and fibrosis [20].

Caspase- 3 is involved in apoptosis of activated HSCs [12]. PRP may promote apoptosis in HSCs through inhibition of TGF- $(31$ as revealed above. Also, PRP appears to decrease nuclear factor-kappa $\mathrm{B}(\mathrm{NF}-\mathrm{\kappa B})$ [21] which is an inflammatory transcription factor that might decrease caspase-3 expression [47]. Moreover, PRP secretes matrix metalloproteinase-9 (MMP-9) initiating apoptosis of HSCs as reported by Hemmann et al., [48]

The diminishing effect of PZQ on $\alpha$-SMA, TGF-( 1 and iNOS expression in this study was in accordance with other studies [29,33-36], whereas, the increment of caspase- 3 expression was in parallel with Abd El-Aal et al., [33] who suggested that the PZQ anti-helminthic action can enhance activation of apoptosis signaling pathways.

In the present study, S. mansoni infection (IU mice) caused significant increase in serum levels of ALT, AST and ALP in comparing with UC mice and this was as per different reports $[\mathbf{3 0 , 3 5}]$. This is due to the associated necrosis of hepatocytes resulting from secreted eggs toxins [49], beside the accompanying oxidative stress [50]. PZQ+PRP achieved the highest lowering of the liver enzymes, followed by PRP and PZQ in comparison with IU mice group with insignificant difference between PRP and PZQ. This PRP effect was in accordance with Shoeib et al., [20] and Salem et al., [21], but in contrast with Takahashi et al., [19] who found 
that human PRP did not influence serum ALT or AST of the fibrotic mice group and this could be explained by the difference of mouse strain, cause of fibrosis or method of PRP administration. On the same context, PZQ significantly diminished the elevated serum liver enzymes in parallel with Sharaf El-Deen et al., [35] and Beshay et al., [30] .

The improvement of liver functions in mice received human PRP in this study could be due to decrease in hepatic fibrosis, improvement of the oxidative status of the hepatocytes and PRP contains of various growth factors that could regenerate the injured hepatocytes like HGF and vascular endothelial growth factor [51]

There are other mechanisms by which PRP might limit hepatic fibrosis. For instances, PRP can suppress hepatocytes apoptosis through promoting HGF secretion from the mice liver as human platelets contain little HGF [52], also, platelets cause regeneration of the hepatocytes as proven in-vivo and in-vitro studies ascribing to releasing of growth factors by them $[\mathbf{3 2 , 5 3 ]}$.

It is worthy mentioned that the platelets have several growth factors with different impacts on the fibrosis development. For example, plateletderived growth factor has a pro-fibrotic effect [54] through induction of HSCs activation, whereas ATP [38] and insulin-like growth factor-1 [55] have anti-fibrotic effect by suppressing HSCs activation. It is hard to clarify the outcome result with PRP administration by few substances inside the platelets. Furthermore, there are numerous cell types in the liver, such as hepatocytes, Kupffer cells and HSCs, that are involved in liver fibrosis [19].

In conclusion, PRP alleviated S. mansoni liver fibrosis primarily by inhibiting activation of HSCs as indicated by decreasing expression of a-SMA and TGF- $\beta 1$, and promoting their apoptosis as demonstrated by increasing expression of caspase3 , as well as lowering oxidative stress by decreasing iNOS expression. In addition, PRP improved the liver functions. Since PZQ kills the schistosomes adults, and PRP has a promising anti-fibrotic effect, it is recommended to use PZQ and PRP in treatment of schistosomiasis mansoni and this could be applicable in human schistosomiasis.

\section{Financial support:}

This work did not recive any financial support from any organization and the cost was paid by the authors.

\section{Conflict of interest:}

None.

\section{References}

1- JOHNSTON E.A., TEAGUE J. and GRAHAM J.P.: Challenges and opportunities associated with neglected tropical disease and water, sanitation and hygiene intersectoral integration programs. BMC Public Health, 11 (15): 547, 2015.

2- WHO: Schistosomiasis. WHO Media Centre, Fact sheet $\mathrm{N}^{\circ} 115$. Available: http://www.who.int/mediacentre/factsheets/fs $115 / \mathrm{en}, 2016$.

3- ADENOWO A.F., OYINLOYE B.E., OGUNYINKA B.I. and KAPPO A.P.: Impact of human schistosomiasis in sub-Saharan Africa. Braz. Infect. Dis. J., 19 (2): 196-205, 2015.

4- CHUAH C., JONES M.K., BURKE M.L., MCMANUS D.P. and GOBERT G.N.: Cellular and chemokine-mediated regulation in schistosome induced hepatic pathology. Trends Parasitol., 30 (3): 141-50, 2014.

5- COLLEY D.G., BUSTINDUY A.L., SECOR W.E. and KING C.H.: Human schistosomiasis. Lancet, 383 (9936): 2253-64, 2014.

6- CARSON J.P., RAMM G.A., ROBINSON M.W., MCMANUS D.P. and GOBERT G.N.: Schistosome-induced fibrotic disease: the role of hepatic stellate cells. Trends Parasitol., 34 (6): 524-40, 2018.

7- SUN X., ZHANG L., WANG J., CHEN J., ZHU D., SHEN $\mathrm{P}$., et al.: Schistosoma japonicum protein $\mathrm{SjP} 40$ inhibits TGF-b1-induced activation of hepatic stellate cells. Parasitol. Res., 114 (11): 4251-57, 2015.

8- DE OLIVEIRA R.B., SENGER M.R., VASQUES L.M., GASPAROTTO J., DOS SANTOS J.P., PASQUALI M.A., et al.: Schistosoma mansoni infection causes oxidative stress and alters receptor for advanced glycation end product (RAGE) and tau levels in multiple organs in mice. Int. J. Parasitol., 43 (5): 371-9, 2013.

9- Poulos T.L. and Li H.: Nitric oxide synthase and structurebased inhibitor design. Nitric Oxide, 63 (28): 68-77, 2017.

10- PAROLA M. and ROBINO G.: Oxidative stress-related molecules and liver fibrosis. J. Hepatol. 35 (2): 297-306, 2001.

11-FAVALORO B., ALLOCATI N., GRAZIANO V., DI ILIO C. and DE LAURENZI V.: Role of apoptosis in disease. Aging (Albany NY) 4 (5): 330-49, 2012.

12-THAPALIYA S., WREE A., POVERO D., INZAUGARAT M.E., BERK M., DIXON L., et al.: Caspase-3 inactivation protects against hepatic cell death and ameliorates fibrogenesis in a diet-induced nash model. Dig. Dis. Sci., 59 (6): 1197-206, 2014.

13-CIOLI D., PICA-MATTOCCIA L., BASSO A. and GUIDI A.: Schistosomiasis control: Praziquantel forever?. Mol. Biochem. Parasitol., 195 (1): 23-9, 2014

14-SINGH K.P., GERARD H.C., HUDSON A.P. and BOROS, D.L.: Expression of matrix metalloproteinases and their inhibitors during the resorption of schistosome egg-induced fibrosis in praziquantel-treated mice. Immunology, 111 (3): 343-52, 2004

15- YOSHIDA K., MURATA M., YAMAGUCHI T., MATSUZAKI K. and OKAZAKI K.: Reversible human TGF-beta signal shifting between tumor suppression and fibro- 
carcinogenesis: Implications of Smad phospho-isoforms for hepatic epithelial-mesenchymal transitions. J. Clin. Med., 5 (1), 2016.

16- ETULAIN J.: Platelets in wound healing and regenerative Medicine. Platelets, 29 (6): 556-68, 2018.

17- SCULLY D., NASEEM K.M. and MATSAKAS A.: Platelet biology in regenerative medicine of skeletal muscle. Acta Physiol. (Oxf), 223 (3): e13071, 2018.

18- MASUKI H., OKUDERA T., WATANEBE T., SUZUKI M., NISHIYAMA K., OKUDERA H., et al.: Growth factor and pro-inflammatory cytokine contents in platelet-rich plasma (PRP), plasma rich in growth factors (PRGF), advanced platelet rich fibrin (A-PRF), and concentrated growth factors (CGF). Int. J. Implant. Dent., 2 (1): 19, 2016.

19- TAKAHASHI K., MURATA S., FUKUNAGA K. and OHKOHCHI N.: Human platelets inhibit liver fibrosis in severe combined mice. World J. Gastroenterol., 19 (32): 5250-60, 2013.

20- SHOEIB H.M., KESHK W.A., FODA A.M. and ABO EL NOEMAN S.E.A.E.: A study on the regenerative effect of platelet-rich plasma on experimentally induced hepatic damage in albino rats. Can. J. Physiol. Pharmacol., 96 (6): 630-36, 2018.

21- SALEM N., HAMZA A., ALNAHDIA H. and AYAZA N.: Biochemical and molecular mechanisms of plateletrich plasma in ameliorating liver fibrosis induced by dimethylnitrosurea. Cell. Physiol. Biochem., 47 (6): 233 139,2018 .

22- MARUYAMA T., MURATA S., TAKAHASHI K., TAMURA T., NOZAKI R., IKEDA N., et al.: Platelet transfusion improves liver function in patients with chronic liver disease and cirrhosis. Tohoku J. Exp. Med., 229 (3): 213-20, 2013.

23- KODAMA T., TAKEHARA T., HIKITA H., SHIMIZU S., LI W., MIYAGI T., et al.: Thrombocytopenia exacerbates cholestasis-induced liver fibrosis in mice. Gastroenterol. 138 (7): 2487-98, 2010.

24- BAUSSET O., GIRAUDO L., VERAN J., MAGALON J., COUDREUSE J.M., MAGALON G., et al.: Formulation and storage of platelet-rich plasma homemade product. Biores Open Access, 1 (3): 115-123, 2012.

25- DUVALL R.H. and DEWITT W.B.: An improved perfusion technique for recovering adult schistosomes from laboratory animals. Am. J. Trop. Med. Hyg., 16 (4): 48386, 1967.

26- CHEEVER A.W.: Conditions affecting the accuracy of potassium hydroxide digestion techniques for counting Schistosoma mansoni eggs in tissues. Bull. World Health Organ., 39 (2): 328-3 1, 1968.

27- FRASER J.A., REEVES J.R., STANTON P.D., BLACK D.M., GOING J.J., COOKE T.G. et al.: A role for BRCA1 in sporadic breast cancer. Br. Cancer J., 88 (8): 1263-70, 2003.

28- WEISKIRCHEN R. and TACKE F.: Liver fibrosis: from pathogenesis to novel therapies. Dig. Dis., 34 (4): 41022, 2016.

29- SOBHY M.M.K., MAHMOUD S.S., EL-SAYED S.H., RIZK E.M.A., RAAFAT A. and Negm M.S.I.: Impact of treatment with a Protein Tyrosine Kinase Inhibitor (Gen- istein) on acute and chronic experimental Schistosoma mansoni infection. Exp. Parasitol., 185:115-23, 2018.

30- BESHAY E.V.N., RADY A.A., AFIFI A.F. and MOHAMED A.H. : Schistosomicidal, antifibrotic and antioxidant effects of Cucurbita pepo L. seed oil and praziquantel combined treatment for Schistosoma mansoni infection in a mouse model. J. Helminthol., 15: 1-9, 2018.

31 - CORREA-OLIVEIRA R., RODRIGUES CALDAS I., MARTINS-FILHO O.A., CARVALHO QUEIROZ C., LAMBERTUCCI J.R., et al.: Analysis of the effects of treatment of human Schistosoma mansoni infection on the immune response of patients from endemic areas. Acta Trop., 77 (1): 141-6, 2000.

32- WATANABE M., MURATA S., HASHIMOTO I., NAKANO Y., IKEDA O., AOYAGI Y., et al.: Platelets contribute to the reduction of liver fibrosis in mice. J. Gastroenterol. Hepatol., 24 (1): 78-89, 2009

33- ABD EL-AAL N.F., HAMZA R.S. and HARB O.: Paeoniflorin targets apoptosis and ameliorates fibrosis in murine schistosomiasis mansoni: A novel insight. Exp. Parasitol., 183: 23-32, 2017.

34- LIANG Y.J., LUO J., YUAN Q., ZHENG D., LIU Y.P., SHI L., et al.: New insight into the antifibrotic effects of praziquantel on mice in infection with Schistosoma japonicum. PLoS One, 6 (5): e20247, 2011.

35- SHARAF EL-DEEN S.A., BRAKAT R.M. and MOHAMED A.S.E.D.: Artichoke leaf extract protects liver of Schistosoma mansoni infected mice through modulation of hepatic stellate cells recruitment. Exp. Parasitol., 178: $51-59,2017$

36- YONES D.A., BADARY D.M., SAYED H.M., BAYOUMI S.A., KHALIFA A.A. and EL-MOGHAZY A.M.: Comparative evaluation of anthelmintic activity of edible and ornamental pomegranate ethanolic extracts against Schistosoma mansoni. Biomed. Res. Int., 2872708, 2016.

37- SHINDE A.V., HUMERES C. and FRANGOGIANNIS N.G.: The role of a-smooth muscle actin in fibroblastmediated matrix contraction and remodeling. Biochim. Biophys. Acta Mol. Basis Dis., 1863 (1): 298-309,2017.

38- IKEDA N., MURATA S., MARUYAMA T., TAMURA T., NOZAKI R., KAWASAKI T., et al.: Platelet-derived adenosine 5'-triphosphate suppresses activation of human hepatic stellate cell: In-vitro study. Hepatol. Res., 42 (1): 91-102, 2012.

39- FRIEDMAN S.L.: Liver fibrosis-from bench to bedside. J. Hepatol., 38 (Suppl. 1): S38-53, 2003.

40- JEONG K.S.: Therapeutic target for chronic liver fibrosis by regulation of transforming growth factor-beta. Basic Applied Pathol., 1 (2): 56-60, 2008.

41- XIA J.L., DAI C., MICHALOPOULOS G.K. and LIU Y.: Hepatocyte growth factor attenuates liver fibrosis induced by bile duct ligation. Am. J. Pathol., 168 (5): 1500-12, 2006.

42- POLJSAK B., SUPUT D. and MILISAV I.: Achieving the balance between ROS and antioxidants: when to use the synthetic antioxidants. Oxid. Med. Cell. Longev., Article ID: 95679, 2013.

43- HIRATA M., HIRATA K., KAGE M., ZHANG M. HARA T. and FUKUMA T.: Effect of nitric oxide synthase inhibition on Schistosoma japonicum egg-induced granuloma 
formation in the mouse liver. Parasite Immunol., 23 (6): 281-89, 2001.

44- NOVOKMET S., JAKOVLJEVIC, V.L.J., JANKOVIC S., DAVIDOVIC G., ANDJELKOVIC N., MILANOVIC Z., et al.: Human platelets perfusion through isolated guinea-pig heart: The effects on coronary flow and oxidative stress markers. Gen. Physiol. Biophys., 28: 98-104, 2009.

45- OSTERMAN C., MCCARTHY M.B.R., COTE M.P., BEITZEL K., BRADLEY J. POLKOWSKI G., et al.: Plateletrich plasma increases anti-inflammatory markers in a human coculture model for osteoarthritis. Am. J. Sports Med., 43 (6): 1474-84, 2015.

46- RAH D.K., MIN H.J., KIM YW. and CHEON Y.W.: Effect of platelet-rich plasma on ischemia-reperfusion injury in a skin flap mouse model. Int. J. Med. Sci., 14 (9): 829 39, 2017.

47- CHEN J., XU T., ZHU D., WANG J., HUANG C., LYU L., et al.: Egg antigen p40 of Schistosoma japonicum promotes senescence in activated hepatic stellate cells by activation of the STAT3/p53/p21 pathway. Cell. Death. Dis., 7 (7): e2315, 2016.

48- HEMMANN S., GRAF J., RODERFELD M. and ROEB, E.: Expression of MMPs and TIMPs in liver fibrosis-a systematic review with special emphasis on anti-fibrotic strategies. J. Hepatol., 46 (5): 955-75, 2007.

49- KADRY S.M., MOHAMED A.M., FARRAG E.M. and FAYED D.B.: Influence of some micronutrients and Citharexylum quadrangular extract against liver fibrosis in
Schistosoma mansoni infected mice. Afr. J. Pharm. Pharmacol., 7 (38): 2628-38, 2013.

50- DE MARIA N., COLANTONL A., FAGIUOLI S., LIU G.J., ROGERS B.K., FARINATI F., et al.: Association between reactive oxygen species and disease activity in chronic hepatitis C. Free Radic. Biol. Med., 21 (3): 291$5,1996$.

51- MAFI A., DEHGHANI F., MOGHADAM A., NOORAFSHAN A., VOJDANI Z. and TALAEI-KHOZANI T.: Effects of platelet-rich plasma on liver regeneration in CCl4-induced hepatotoxicity model. Platelets, 27 (8): 771-76, 2016.

52- HISAKURA K., MURATA S., TAKAHASHI K., MATSUO R., PAK S., IKEDA N., et al.: Platelets prevent acute hepatitis induced by anti-fas antibody. J. Gastroenterol. Hepatol., 26 (2): 348-55, 2011.

53- MATSUO R., OHKOHCHI N., MURATA S. IKEDA O., NAKANO Y., WATANABE M., et al.: Platelets strongly induce hepatocyte proliferation with IGF-1 and HGF invitro. J. Surg. Res., 145 (2): 279-86, 2008.

54- CZOCHRA P., KLOPCIC B., MEYER E., HERKEL J., GARCIA-LAZARO J.F., THIERINGER F., et al.: Liver fibrosis induced by hepatic overexpression of PDGF-B in transgenic mice. J. Hepatol., 45 (3): 419-8, 2006.

55- SOBREVALS L., RODRIGUEZ C., ROMERO-TREVEJO J.L., GONDI G., MONREAL I., PAÑEDA A., et al.: Insulin- like growth factor I gene transfer to cirrhotic liver induces fibrolysis and reduces fibrogenesis leading to cirrhosis reversion in rats. Hepatol., 51 (3): 912-21, 2010. 


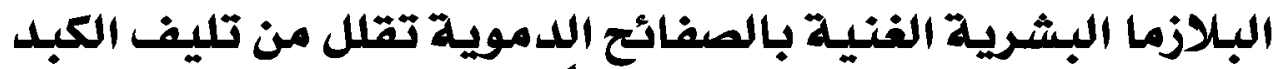

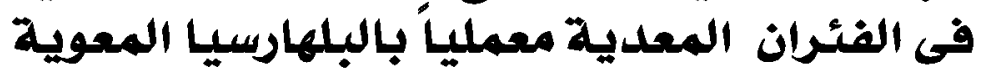

إن الإصابة بمرض البلهارسيا المعوية تؤدى إلى التليف الكبدى الذى قد يسبب مضاعفات شديدة. وحتى الآن لا يوجد دواء فعال

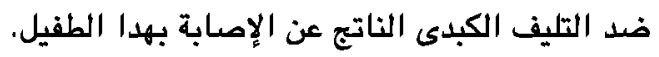

الهدف من هذه الدراسة: هو تقييم تأثير البلازما البشرية الفنية بالصفائح الدموية ضد التيف التيف الكبدى الناتج عن البلهارسيا المعوية فى الفئران المعدية معملياً وحدها أو بالأشتراك مع بالير البارنما البشرية الفيكوانتيل. قد تم تقسيم الفئران إلى خمس مجموعات :

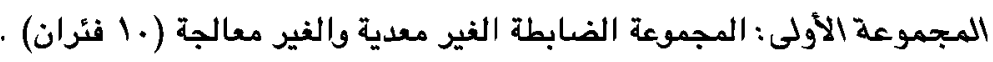

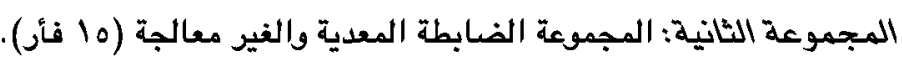

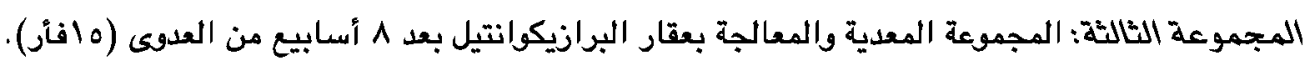

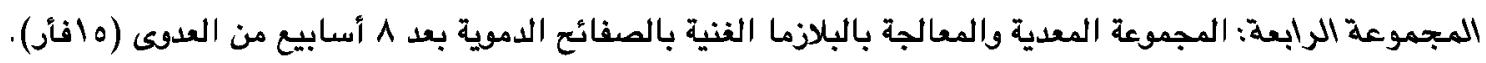

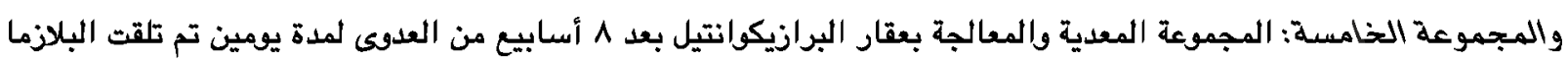

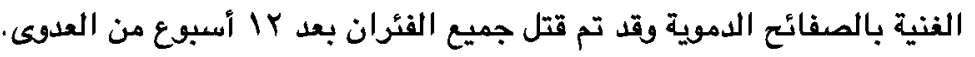

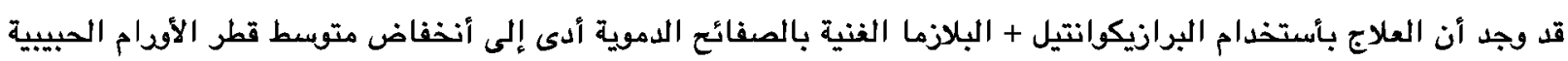

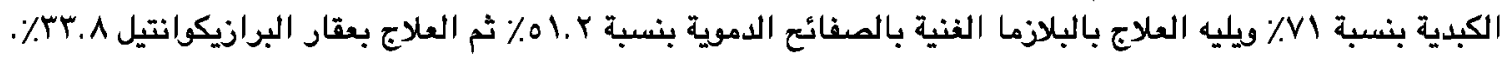

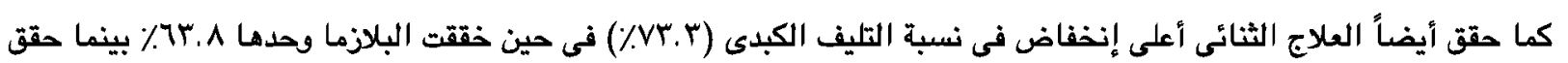

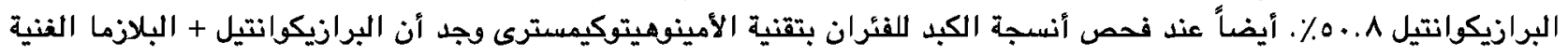

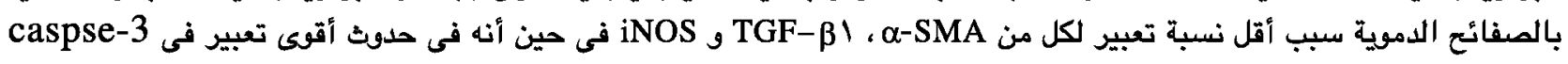

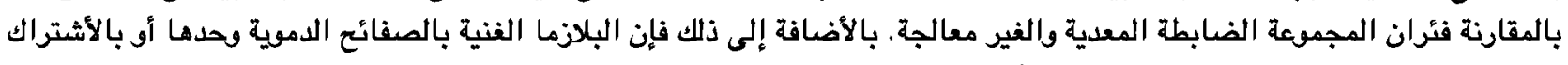

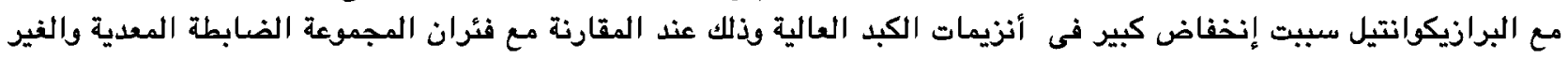
معالجة.

الخلاصة: أن البلازما الفنية بالصفائح الدموية قد قللت من نسبة التليف الكبدى عند فئران التجاربالمعدية معملياً الفياً بالبلهارسيا

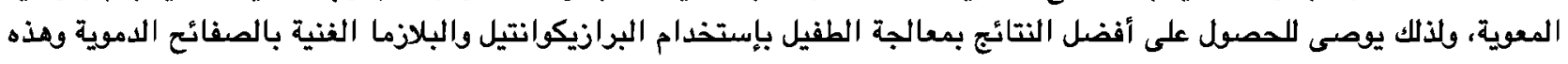

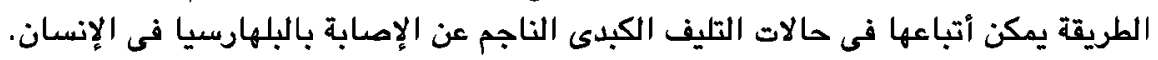

